\title{
PRESENT STATUS OF INTERTIDAL BIODIVERSITY IN AND AROUND MUMBAI (WEST COAST OF INDIA)
}

Kulkarni BALASAHEB *, Babar ATUL *, Jaiswar ASHOK ** and Kolekar RAHUL *

* Department of Marine Biology, The Institute of Science, Madam Cama Road 15, Mumbai, IN-400032, balasahebk@yahoo.com, babaratul_g@yahoo.co.in,kumarkolekar@gmail.com

** Central Institute of Fisheries Education, Versova, Mumbai, IN-400061, akjaiswar@cife.edu.in

DOI: 10.1515/trser-2017-0006

KEYWORDS: intertidal, mollusc, benthos, algae, echinoderm, crustacean, fish.

\section{ABSTRACT}

During the present investigation, Girgaon, Marine Drive, Haji Ali and Gorai Creek in Mumbai were selected for biodiversity assessment following a protocol for natural geography in shore areas. Fifty nine macrobenthic molluscs, arthropods, coelenterates and echinoderms at these sites were recorded. The maximum density of gastropods and clams was observed at Marine Drive shore. At Gorai Creek, there were plentiful Telescopium telescopium, Potamidus cingulatis, mudskipper and fiddler crabs. Studies shows that the biodiversity status of the selected sites varies with respect to location, type of substratum and season. Pollution was observed to have a noticeable effect on clams at Girgaon coast, where many Paphia textile shells were observed to be filled with mud and coated with black colour.

RESUMEN: Situación actual de la biodiversidad intermareal en y alrededor de Mumbai (Costa Oeste de la India).

Durante la investigación actual, Girgaon, Marine Drive, Haji ali, Gorai Creek en Mumbai fueron seleccionados para la evaluación de la biodiversidad siguiendo la geografía natural en el protocolo de las áreas de la orilla. Se recodificaron 59 moluscos macrobentónicos, artrópodos, celentéreos y equinodermos en estos sitios. Na costa de Marine Drive, la densidad máxima de los gastrópodos y de la almeja. En el Gorai Creek, muchos Telescopium telescopium, Potamidus cingulatis, pez de fango y cangrejos violinistas fueron detectados. Los estudios sobre el índice de diversidad de Shannon y Simpson, el índice de riqueza de Margalef y el índice de equidad de Pielou muestran que el estado de la biodiversidad de los sitios seleccionados varía con respecto a la ubicación, tipo de sustrato y estación. El efecto de la contaminación en la costa de Girgaon se observó en las almejas Paphia textile donde las conchas rellenas de fango y cubiertas de manchas de color negro fueron observadas.

REZUMAT: Situația actuală a biodiversității din zona litorală în și dimprejurul regiunii Mumbai (Coasta de Vest a Indiei).

În cadrul investigațiilor din Girgaon, Marine Drive, Haji ali și pârâul Gorai în Mumbai au fost alese pentru investigarea biodiversității urmând protocolul de geografie naturală a zonelor de țărm. Au fost înregistrate 59 de moluște macrobentice, artropode, celenterate și echinoderme la aceste locații. La țărmul Marine Drive a fost înregistrată o densitate maximă a gastropodelor şi scoici. La pîrâul Gorai au fost înregistrate următoarele specii: Telescopium telescopium, Potamidus cingulatis, peşti amfibii şi crabi. Studii ale indicilor de diversitate Shannon şi Simpson, indicele Margalef și indicele Pielou arată că situaţia biodiversităţii din locațiile selectate variază în funcție de amplasare, tip de substrat și sezon. Efectul poluării pe coasta Girgaon a fost observat în cazul scoicilor unde multe exemplare de Paphia textile au fost găsite pline de mâl și acoperite cu o substanță de culoare neagră. 


\section{INTRODUCTION}

India is well known arround the world for a very high aquatic biodiversity (Jeeva et al., 2011; Sanghvi et al., 2015; Ramanibai and Govindan, 2015). Mumbai (1853' to $19^{\circ} 16^{\prime}$ N latitude and $72^{\circ} 48^{\prime}$ to $72^{\circ} 53^{\prime}$ E longitude) is an island situated on the west coast of the Indian peninsula on the Arabian Sea. Mumbai was built on cluster of seven islets. Now it forms a mass of islands, measuring three miles in width. This area northern end to rock at Colaba and its southern end at the Northern Kokan coast. A deep natural harbour is located to the east and at the south part off Colaba Point there is the Prong's Reef reefs area, which is unprotected in spring low tide. The rocks of these reef areas lengthen up to the Nariman Point. The island is linked at its northern part with the larger Salsette Island by two causeways, at Mahim one and the other at Sion. (Jaiswar, 1999)

Mumbai is a significant industrial hub in India, with representatives of everything from textiles to petrochemicals, and it is responsible for half of India's foreign trade. Moreover, Mumbai has a very long coastline of $100 \mathrm{~km}$. Although the majority of the population of Mumbai is provided with houses and sanitary facilities, almost half of the city's 12 million residents are either slum dwellers or homeless. They occupy $6 \%$ of the city's land. The sewage from the residential areas of Colaba, Worli, Malad and Bandra is into the coastal area through marine outfalls with a capacity of 4.1 MLD, 756.4 MLD and 0.80 MLD, whereas sewage from other area is released into neighboring creeks. Due to human pressures, the shore area of Mumbai is highly degraded. The shore zone of Mahim used to have a very rich faunal diversity some thirty years ago, but now it has deteriorated to such a condition that the benthic fauna has been totally wiped out. (Jaiswar, 1999)

Since massive amount of domestic and tannery industrial waste is released into the Mahim shore area, the area has been converted to an ecological dead-zone. Similar conditions are likely to occur in the remaining intertidal areas in and around Mumbai. Due to increasing pollution in shore waters around Mumbai, there are reports of habitat destruction and species loss. Nearly $8 \%$ of industries in the country are located around Mumbai in four large industrial clusters namely Trans Thane-Belapur belt, Kalyan-Ulhasnagar-Ambernath belt, western bank of Thane Creek and around the Patalgang Amba rivers. Patalganga, Amba and Ulhas rivers, and Thane Creek are the receivers of a mixture of waste. The amount of water supplied for drinking, commercial, industrial and recreational purpose in Mumbai was 3,193 MLD whereas for the year 2021 it is estimated to be 5,388 MLD (Nallathiga, 2006). Therefore plenty of waste water is generated from domestic and industrial sources and majority of it is released directly into shore waters in Mumbai.

For many years, there has been a long-term study of an intertidal area in and around Mumbai. Bal and Parham (1945, 1946) recorded normal chemical and physical conditions of shore water of Bombay harbour with an abundance of plankton. Most of the earlier reports on the intertidal diversity of Mumbai are limited in goal (Abercrombie, 1893; Melvill and Standen, 1910; Subramnyam et al., 1949, 1951, 1952; Bhatt, 1959). Therefore, this investigation selected four shore areas in and around Mumbai to assess their biodiversity status and the impacts and effects of human activity on biodiversity patterns. 


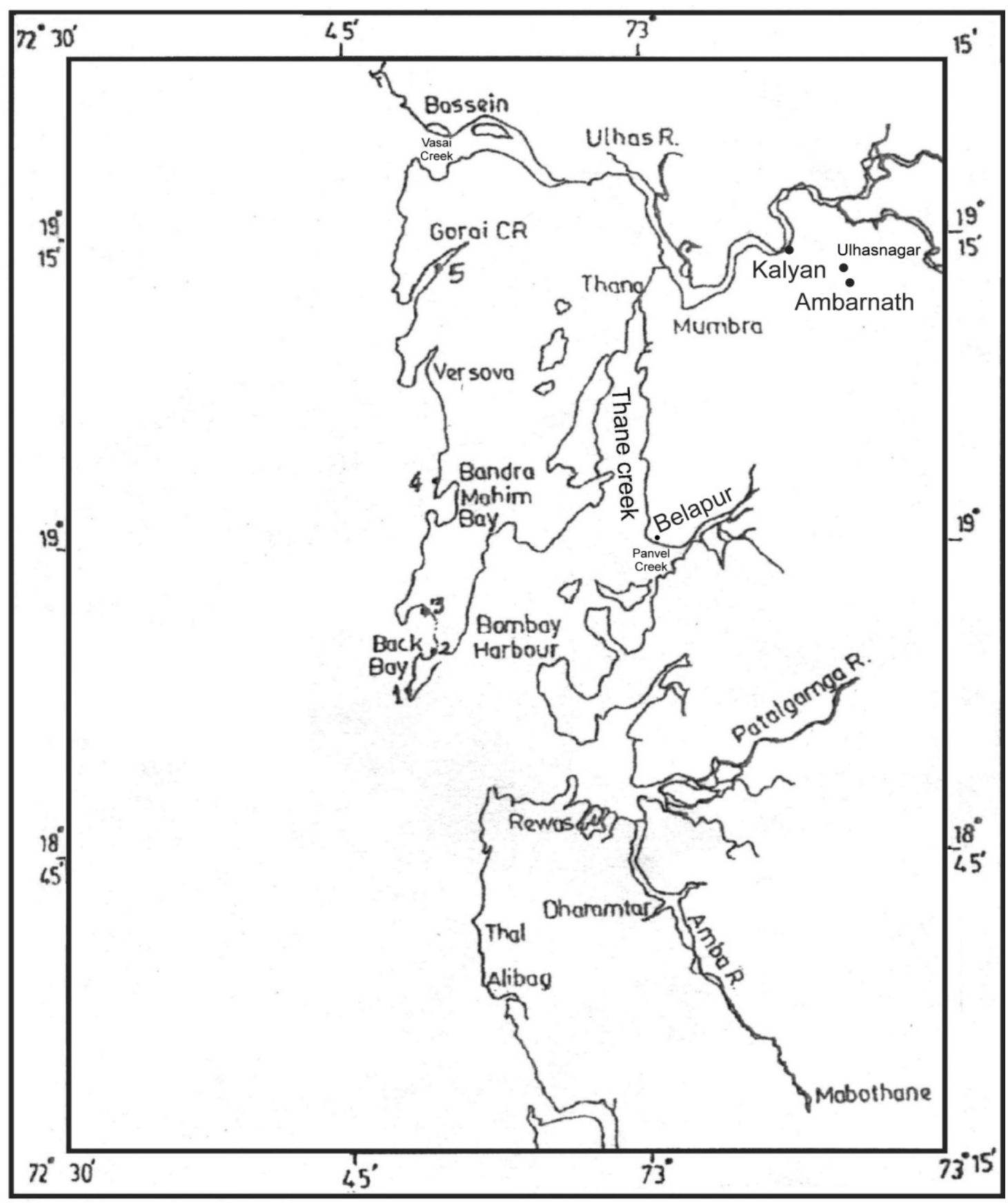

Figure 1: Map of Mumbai showing selected shore area study sites. 


\section{MATERIAL AND METHODS}

\section{The Study Sites}

Intertidal zones at Girgaon, Marine drive, Haji ali in the south and Gorai Creek in the north of Mumbai were selected for the present investigation. The Girgaon Chowpatty Intertidal Area is located in south Mumbai and is popular as, it constitutes a part of the Queen's Necklace shore. It is sandy in nature and is one of the famous recreational areas in Mumbai. Even though it has a large pan of coarse sand, biggest of the uppermost part of it is jammed with food and snack stalls. Furthermore thousands of people visit it everyday and maximum human activities takes place here. As a result the shore is in a deteriorating condition.

In addition, there is extensive storage of garbage including plastic bags, flowers, waste paper, which brings more stress on marine biota, especially at the upper intertidal zone, the lower part of shore area still possesses a variety of fauna. The sand at this site is composed of variety of mineral species in both the coarser and finer fractions. Disintegrated shell matter, which occurs in both coarse and fine fractions along with coral fragments and microfossils, was found to make up a considerable portion of beach sediment. The common minerals of the light fraction like calcite, feldspar and clay were also noticed substantially at this shore. Calcite, which is found to be a major mineral constituent of sand here, is mainly derived from the disintegration of larg mollusc shells, corals and foraminifer skeletons. The middle and lower intertidal areas of Girgaon Chowpatty have muddy substratum of mixed silt and sand, providing a suitable habitat for burrowing bivalves like blood clam.

At the Girgaon Chowpatty coast, there is significant release of domestic waste containing big quantities of particulate matter. Such particulate matter settles down on sandy shore and forms a muddy substratum. Moreover every year large number of Ganpati idols are immersed here after Ganpati festival. All these idols are create of Plaster of Paris and clay, which when sink in sea water dissolve to produce a fine-grained substance which forms a muddy base after combining with sand. An area with mudd of this kind is evident in the intermediate intertidal zone. Wave action is minimal on the muddy shore where the slope is gentle and the area is called a Mudflat. The water content of this area is considerably high at low tide.

The Marine Drive and Haji Ali coasts are rocky. The Marine Drive coast sector is three km long at the shore end at Girgaon Chopatty. It also part of the Queen's Necklace shore area. As with Girgaon Chowpatty, both Marine Drive and Haji Ali are also very touristic areas, with numerous hotels which are located near the Marine Drive sector. The waste released here combines with the fine grained material from dissolved idols at Girgaon Chowpatty, and collectively have a great influence on the physiochemical property of the water and ultimately the biodiversity of Marine Drive sea shore. The upper intertidal area is artificially reclaimed with large size cement tetrapod shape blocks and a road wall.

Mahalaxmi-haji-ali shore is located in South Mumbai. The area mainly consists of basalt rocks in the upper intertidal areas with sporadic patches of sand. Nevertheless, upper and partialy the middle zone are muddy with big pebbles. Because dousehold discharges are released here, there is an continuous process of muddy base creation.

Gorai Creek which transects the northwest portion of Mumbai extends $12 \mathrm{~km}$ inland through vast mangrove mudflats and low lying marshy areas. The shallow creek of Gorai is influenced by semi-diurnal tides. The discharge of domestic effluent in the inner part of the creek exerts some influence on the ecosystem. 


\section{Sampling method}

The picked shore sectors in and around Mumbai area were inspected monthly at the same time with low tides from July 2009 to January 2011. The principal sampling method was quadrat sampling following the guidelines given by NaGISA (Natural geography in shore areas). Voucher specimens of macro benthic species were collected from the respective shore areas, brought to the laboratory for identification and deposited in departmental specimen repository. Identification of molluscs was done following the reports by Subramanyam et al. (1949, 1951 and 1952). The taxonomy of crabs were identified using a report by Chhapgar (1957, 1958), and other groups like crustacean and annelids were identified using a paper by Bhatt (1959).

\section{RESULTS AND DISCUSSION}

The of microbenthic species diversity recorded in selected shore sectors in and around Mumbai is given in table 1 . The data reveal that in the macrobenthic fauna prevails the gastropods and the bivalves. Further shore specific distribution of the benthos was also noticed. Plastic bottles, plastic food wrappers and polyethylene bags were also noticed on the surface water up to 100 meter inside from the coast of all the stations.

Girgaon chopatty shore: Since Girgaon's substrate is sandy-muddy in nature, it is dominated by clams and gastropods. Of the clam family, the most abundant species were Paphia textile and blood clam Arca sp. Of the gastropod family, Babilonia spirata dominated. Nevertheless, the other macrobenthic species presence was sparce, particularly in comparison with other study areas. There is significant deposition of silt and organic matter which support the local detritus feeding species. Nevertheless, the breaking down of particles leads to the detection of oxygen which induces in the formation of Sulphite black layer. This layer fluctuates in various sectors of the shore, and the interaction between alluvium and leads microorganisms induce the Hydrogen sulphite creation. Such black layer was noticed here and shells of most gastropods inhabiting this area were found to be coated with blackish colour.

Marine Drive shore: 34 macrobenthos species were sampled in the Marine Drive rocky shore area. Dominant in the macrobenthos were the molluscs (24 species) and the bivalves (eight species). There was clear dominance of Euchelus asper (8-78\%) followed by Gafrarium divaricatum (8-21\%) and Pyrene atrara (0-28\%). The dominance of gastropod and clams in this study area was similar to that reported by Jaiswar and Kulkarni (2005). The crustaceans were essentially represented by four crab species (viz. Eriphia sp. (Red eye reef crab), Petrolisthes sp. (Red porcelain crab), Schizophrys aspera (spider crab) and Charybdis japonicas (Asian paddle crab)), two pistol shrimp species (viz. Alpheus euphrosyne, Alpheus heterochaelis) and one barnacle species (Balanus amphitrite), found in and on the boulders and rocks of Marine Drive shore. Large-sized B. amphitrite was noticed in the middle zone. A juvenile octopus and Moray eel were also sampled exceptionally from the lower intertidal sector in the research period. Cement terapods put here found to provide substratum for Neretidae, oysters and Balanus species to colonise. There are also some species of crabs hiding under the blocks. 
Table 1: Diversity of Macrobenthos species at Girgaon Chopatty (GIC), Marine Drive Shore (MD), Haji Ali shore (HA) and Gorai Creek (GC) in Mumbai.

\section{Pelecypoda}

\begin{tabular}{|c|l|l|l|}
\hline Family & \multicolumn{1}{|c|}{ Species } & \multicolumn{1}{|c|}{ Occurrence } & \multicolumn{1}{|c|}{ Place } \\
\hline Mytilidae & Modiolus emerginatus (Benson, 1858) & Rare & GIC \\
& Perna viridis (Linnaeus, 1758) & Common & MD,GC,HA \\
\hline Veneridae & Katelysia opima (Gmelin, 1791) & Common & GC \\
& Gafrarium divaricatum (Gmelin, 1791) & Common & HA \\
& Gastrena polygona (Gmelin, 1791) & Common & HA \\
& Venerupis microphylla (Deshayes, 1853) & Common & GIC \\
& Dosinia gibo (Gmelin, 1791) & Common & MD, GIC, \\
& Cardita antiquata (Linnaeus, 1758) & Common & HA G, GIC, \\
& & & HA \\
\hline Ostreidae & Crassostrea cucullata (Born, 1778) & Common & MD, HA, \\
& C. gryphoides (Schlotheim, 1813) & Gommon & HA \\
& Saccostrea cucullata Ignaz von Born 1778 & Common & GC, HA, \\
& & & GRC \\
& & & \multicolumn{2}{|c|}{} \\
\hline
\end{tabular}

\begin{tabular}{|c|c|c|c|}
\hline \multicolumn{4}{|l|}{ Gastropoda } \\
\hline Trochidae & \begin{tabular}{|l|} 
Trochus stellatus (Gmelin, 1791) \\
T. tentorium (Gmelin, 1791) \\
T. radiatus (Gmelin, 1791) \\
Clancules ceylonicus (Nevill, 1869) \\
Euchelus asper (Gmelin, 1791)
\end{tabular} & $\begin{array}{l}\text { Common } \\
\text { Common } \\
\text { Common } \\
\text { Common } \\
\text { Common }\end{array}$ & $\begin{array}{l}\text { HA } \\
\text { MD, HA } \\
\text { MD, HA } \\
\text { HA, } \\
\text { MD, HA }\end{array}$ \\
\hline Neritidae & \begin{tabular}{|l|} 
Nerita oryzarum (Recluz, 1841) \\
N. albicilla (Linnaeus, 1758) \\
Nerita crepidularia (Lamarck, 1822) \\
N. pulchella (Recluz, 1843)
\end{tabular} & $\begin{array}{l}\text { Plentiful } \\
\text { Common } \\
\text { Common } \\
\text { Common }\end{array}$ & $\begin{array}{l}\text { MD, HA } \\
\text { MD, HA } \\
\text { HA } \\
\text { HA }\end{array}$ \\
\hline Planaxidae & Planaxis sulcatus (Born, 1778) & Plentiful & MD, HA \\
\hline Potimididae & \begin{tabular}{|lcc} 
Potamides cingulatus (Gmelin, 1791) \\
Telescopium telescopium (Linnaeus, 1758)
\end{tabular} & $\begin{array}{l}\text { Plentiful } \\
\text { Plentiful }\end{array}$ & $\begin{array}{l}\text { GC, HA } \\
\text { GC }\end{array}$ \\
\hline Bursidae & $\begin{array}{l}\text { Bursa tuberculata (Broderip, 1833) } \\
\text { B. spinosa (Schumacher, 1817) } \\
\text { B. granulose (Roding, 1798) } \\
\text { Bursa elegans (Sowerby, 1835) }\end{array}$ & $\begin{array}{l}\text { Plentiful } \\
\text { Common } \\
\text { Common } \\
\text { Plentiful }\end{array}$ & $\begin{array}{l}\text { MD, GIC, } \\
\text { HA, GC } \\
\text { MD, HA } \\
\text { GC, HA } \\
\text { GC, HA }\end{array}$ \\
\hline Muricidae & $\begin{array}{l}\text { Thais bufo (Lamarck, 1822) } \\
\text { Drupa tuberculata (Blainville, 1832) }\end{array}$ & $\begin{array}{l}\text { Common } \\
\text { Common }\end{array}$ & $\begin{array}{l}\text { MD, HA, GC } \\
\text { HA }\end{array}$ \\
\hline Buccinidae & $\begin{array}{l}\text { Babylonia spirata (Linnaeus, 1758) Pyrene } \\
\text { atrata (Gould, 1860) }\end{array}$ & $\begin{array}{l}\text { Common } \\
\text { Common }\end{array}$ & $\begin{array}{l}\text { MD, GIC, } \\
\text { HA } \\
\text { MD }\end{array}$ \\
\hline Volemoidae & Hemifusus pugilinus (Born, 1778) & Common & $\begin{array}{l}\text { MD, GIC, } \\
\text { HA, GC }\end{array}$ \\
\hline Cypraeidae & Cypraea arabica (Linnaeus, 1758) & Rare & MD \\
\hline Fissurellidae & Scutus unguis (Linnaeus, 1758) & Common & $\mathrm{MD}, \mathrm{HA}$ \\
\hline Onchidiidae & Onchidium peronii (Cuvier, 1804) & Common & MD \\
\hline
\end{tabular}


Table 1 (continued): Diversity of Macrobenthos species at Girgaon Chopatty (GIC), Marine Drive Shore (MD), Haji Ali shore (HA) and Gorai Creek (GC) in Mumbai.

\section{Cephalopoda}

\begin{tabular}{|c|c|c|c|}
\hline Octopodiformes & Octopus vulgaris (Lamarck, 1798) & Common & MD \\
\hline \multicolumn{4}{|l|}{ Crustacea } \\
\hline Xanthidae & $\begin{array}{l}\text { Epixanthus frontalis (H. Milne Edwards, } \\
\text { 1834) } \\
\text { Leptodius exaratus (H. Milne Edwards, } \\
\text { 1834) }\end{array}$ & $\begin{array}{l}\text { Common } \\
\text { Common }\end{array}$ & $\begin{array}{l}\text { GC } \\
\text { GC }\end{array}$ \\
\hline Eriphiidae & Eriphia sp. & Common & MD, HA \\
\hline Majidae & $\begin{array}{l}\text { Schizophrys aspera (H. Milne Edwards, } \\
\text { 1834) }\end{array}$ & Common & $\mathrm{MD}, \mathrm{HA}$ \\
\hline Porcellanidae & Petrolisthes boscii (Audouin, 1826) & Common & MD, HA, GC \\
\hline Portunidae & $\begin{array}{l}\text { Charybdis japonica (A. Milne-Edwards, } \\
\text { 1861) }\end{array}$ & Common & MD, HA, GC \\
\hline Ocypodidae & $\begin{array}{l}\text { Uca annulipes (H. Milne Edwards, 1837) } \\
\text { U. vocans (Linnaeus, 1758) } \\
\text { Uca dussumieri (H. Milne Edwards, 1852) }\end{array}$ & $\begin{array}{l}\text { Common } \\
\text { Common } \\
\text { Common }\end{array}$ & $\begin{array}{l}\text { HA, GC } \\
\text { HA, GC } \\
\text { GRC }\end{array}$ \\
\hline Balanidae & $\begin{array}{l}\text { Balanus variegatus (Darwin, 1854) } \\
\text { Balanus amphitrite (Darwin, 1854) }\end{array}$ & $\begin{array}{l}\text { Common } \\
\text { Common }\end{array}$ & $\begin{array}{l}\text { GRC, HA } \\
\text { MD }\end{array}$ \\
\hline Paguridea & Eupagurus prideauxi (Leach, 1815) & Common & GRC, HA \\
\hline Alpheidae & $\begin{array}{l}\text { Alpheus euphrosyne (de Man, 1897) } \\
\text { Alpheus heterochaelis (Say, 1818) }\end{array}$ & $\begin{array}{l}\text { Common } \\
\text { Common }\end{array}$ & $\begin{array}{l}\text { MD, HA } \\
\text { MD, HA }\end{array}$ \\
\hline \multicolumn{4}{|l|}{ Porifera } \\
\hline Lecosolenidae & $\begin{array}{l}\text { Leucosolenia complicata (Montagu, 1814) } \\
\text { Tetilla dactyloidea (Ridley, 1884) } \\
\text { Tethya lyncurium (Linnaeus, 1767) }\end{array}$ & $\begin{array}{l}\text { Common } \\
\text { Common } \\
\text { Common }\end{array}$ & $\begin{array}{l}\text { MD, HA } \\
\text { MD, HA } \\
\text { MD, HA }\end{array}$ \\
\hline \multicolumn{4}{|l|}{ Coelentelata } \\
\hline Actinidae & $\begin{array}{lll}\text { Metridium marginatum } & \text { (H. } & \text { Milne- } \\
\text { Edwards, 1834) } & & \\
\end{array}$ & Common & $\begin{array}{l}\text { MD, HA, } \\
\text { GIC }\end{array}$ \\
\hline \multicolumn{4}{|l|}{ Fish } \\
\hline Gobiidae & $\begin{array}{l}\text { Boleophthalmus boddaerti (Pallas, 1770) } \\
\text { B. viridis (Hamilton, 1822) }\end{array}$ & $\begin{array}{l}\text { Plentiful } \\
\text { Plentiful }\end{array}$ & $\begin{array}{l}\text { MD, HA, } \\
\text { GRC, GC } \\
\text { GRC }\end{array}$ \\
\hline Muraenidae & Maoray eel & Threatened & $\mathrm{MD}, \mathrm{HA}$ \\
\hline
\end{tabular}


Haji-Ali shore: There were a total of 30 species of macrobenthos observed during the surveys. The shores of this area were dominated by gastropods with seven genera, four species of bivalve, and in some regions dense population of sea anemones. The sea shore of Haji-Ali is dominated by Euchelus asper (17-42\%) followed by Bursa tuberculata (9-22\%) and Trochus radius (5-21\%). There was a unique presence of the bivalve Gastrena polygona recorded here. G. polygona was not detected at any other intertidal area of the Mumbai shore. G. polygona was found in the muddy substratum in the Middle and Lower zone. During low tide, the long red siphon of G. polygona was found to sprinkle water - an activity that was used to find its location. Also present in significant numbers were the edible bivalve G. divaricatum, Dosinia gibba and Crassostrea cucullata.

Gorai Creek shore: In Gorai Creek five algal species were rarely sampled. Species of Sargassum, Gracilaria, Ulva, Entermorpha and Chaetomorpha were detected here, although their density was limited. All the species were found in a healthy condition with respect to coloration and condition of leaves. In the mudd of Gorai shore, were registered high densities of Boleophthalmus, mainly B. boddaerti and B. viridis. Alongside this, mainly molluscs and arthropods were recorded in Gorai Creek. Among the gastropods present, Telescopium telescopium and P. cingulata were found abundantly. In comparison with these gastropods, the occurrence of bivalve species was uneven and less dense. Venerupsis microphylla species was sampled and registered for the first time in the shore sectors of the creek. Arthropod fauna was identified mainly as crustaceans which included crabs from 14 species and 10 genera. Among the crabs, the fiddler or dhobi crabs of three species were found abundantly in marshy places in mangrove swamps. During ebb tides these crabs were seen to swarm out from their burrows. Thalamita crenata was found infrequently. A family Grapsidae species was sampled plentifully in human-made structures of stone and craks in wooden elements of a bridge.

Many previous investigators assessed the biodiversity of east and west coasts of India from time to time. Biodiversity patterns monitoring of the Indian coast is missing and complete data about biota dispersion for numerous areas of Indian coast is not available. Abercrombie (1892) and Melvill and Standen (1910) had assessed molluscan diversity of gastropods and bivalves at intertidal areas of the Bombay Presidency. Chhapgar $(1957,1958)$ had studied status of crabs from intertidal areas in Bombay. The National Institute of Oceanography (NIO) achieved out the first complete assessment of the Uran coast in 1986. Likewise Babu (1999) researched mangroves and associated fauna of the Uran coast area. Given this data incoherency and inconsistency, the data given in this research of macro-benthic fauna can represent a base line for future comparisons.

Bhatt (1959) has reported twenty four species of algae, two species of sponges, forty three species of crabs, six species of Balanus, fifty nine species of gastropod and thirty one species of bivalve from various shore areas of Mumbai. Shore areas monitored by Bhattt (1959) includes Cuffe Parade, the Secretariat foreshore, Chowpatty Sand, Chowpatty Rocks, Breach candy, Dadar and Mahim. The areas between Haji Ali and Worli have not been surveyed. Other lotic systems like Gorai in Mumbai have not been researched for macrobenthos. Therefore the base line data on macrobenthos in these areas are not available. Furthermore, Bhatt (1959) recorded twenty four species of algae but during the present investigation only ten species of algae were detected in Gorai Creek. The reduction in number of algal species noted clearly indicates anthropogenic pressure on this fragile community. Except for species of Caulerpa and Dictyota, brown alga and other species were not found abundantly in these areas. 
The gastropod species of Planaxis sulcatu, Bursa tuberculata, B. spinosa, B. granulose, Nerita oryzarum, Natica maculosa and others given in table 1 were reported in earlier studies of the shore areas of Mumbai (Bhatt, 1959; Jaiswar, 1999). However, the regular presence of these gastropods at the study sites suggests that they have adapted well to the changes in environmental conditions, as the earlier studies indicate them to be rare or missing. During the present investigation, the bivalve Gastrana polygona was detected only at Haji-Ali and presence of this clam was not reported by Bhatt (1959). Jaiswar and Kulkarni (2005) also noted a rare occurrence of $G$. polygona. Further presence of oysters at rocky shore of Worli indicates suitability of the shore for oyster growth. Crassostrea gryphoides was found by Bhatt (1959) and Jaiswar and Kulkarni (2005). But during the present investigation, C. gryphiodes was mainly detected in higher densities in the middle part of the rocky shore. Seven species of crabs recorded on the Worli shore also suggest that the rocky shore here is helpful in providing a habitat for these crabs. Rocks and boulders in the area create crevices and other hiding place for the crabs.

The presence of three species of Antedon (feather star) and one species of Echinus (Temnopleurus toreumaticus) is a unique diversity characteristic observed near Mumbai coastal waters. Until now, no one has reported the presence of such number of echinoderms in and around the Mumbai shore (NIO, 1986). Jaiswar and Kulkarni (2005) reported sporadic distributions of Placenta placenta in shore waters of Mumbai, although the effects of pollution on $P$. placenta have been reported by Jaiswar (1999). The crabs recorded here were also reported by Chhapgar (1957). Further, Subrhmnyam et al. (1952) had reported gastropods and bivalves in intertidal areas of Mumbai. But during the present investigation, species diversity of molluscs was observed to have declines in comparison with earlier studies. The obvious existence of pollution sources indicates the effect of human pressures on shore in the Mumbai city area.

\section{CONCLUSIONS}

This study has provided a first baseline of intertidal macrobenthic species in the Mumbai area. It indicates that intertidal macrobenthic species are declining, and threatened by increasing human pressures on this habitat. In conclusion it is necessary to have in deep survey of whole Mumbai and nearby shore areas for a more accurate knowledge of the biodiversity status of the area, and to permit ongoing monitoring of the situation. It will also be important to take steps to address ongoing issues such as the release of untreated waste water from domestic and industrial sources, if macrobenthic species and habitats are to recover. 


\section{REFERENCES}

1. Abercrombie A., 1892 - The common marine shells of Bombay shore, Journal of Bombay natural History Society, 8, 212-222.

2. Babu K. N., 1999 - Environmental studies in relation to Mangroves, PhD thesis, University of Mumbai.

3. Bal D. V. and Pradhan L. B., 1945 - A preliminary note on the plankton of Bombay harbour, Current Science, 14, 8, 212-212.

4. Bal D. V. and Pradhan L. B., 1946 - A preliminary record of some of the chemical and physical conditions in water of Bombay harbour during 1944-1945, Proceedings Indian Academy Sciences, 24, 2, 60-65.

5. Bhatt Y. M., 1959 - A study of the intertidal organisms of Bombay, PhD thesis, University of Bombay.

6. Chhapgar B. F., 1957 - On the marine crabs (Decapoda-Brachyura) of Bombay state, Journal of Bombay natural History Society, 54, 399-439.

7. Chhapgar B. F., 1958 - More additions to the crab fauna of Bombay state, Journal of Bombay natural History Society, 65, 3, 606-617.

8. Jaiswar A. K., 1999 - Intertidal biodiversity with reference to mollusks in and around Mumbai, PhD thesis, University of Mumbai.

9. Jaiswar A. K. and Kulkarni B. G., 2005 - Conservation of molluscan biodiversity from intertidal area of Mumbai coast, Journal of Nature conservation, 17, 1, 93-105.

10. Jeeva V., Kumar S., Verma D. and Rumana H. S., 2011 - River fragmentation and connectivity problems in Gange River of upper Himalayas: the effect on the fish communities (India), Transylvanian Review of Systematical and Ecological Research, 12, 75-90.

11. Melvill J. C. and Abercrombie A., 1893 - The marine mollusks of Bombay Memoir and Proceedings, Manchester Literature and Philosophy Society Series, 7, 17-51.

12. Nallathiga R., 2006 - Reforming water sector governance and institutions for improving efficiency: the case of Mumbai, International Journal of Regulation and Governance, 6, 1, 99133.

13. Sanghvi D., Ray Chaudhury N. and Jain B., 2015 - Microhabitat preferences of Phaeophyta on shore platform of Dwarka, Gujarat Coast, India, Transylvanian Review of Systematical and Ecological Research, 17.2, 11-22.

14. Subramanyam T. V., Karindikar K. R. and Murthi N. N., 1949 - Marine pelecypods of Bombay, Journal of University of Bombay, 17, 50-81.

15. Subramanyam T. V., Karindikar K. R. and Murthi N. N., 1951 - Marine gastropods of Bombay, Part I, Journal of University of Bombay, 20, 21.

16. Babu K. N., 1999 - Environmental studies in relation to Mangroves, PhD thesis, University of Mumbai.

17. Bal D. V. and Pradhan L. B., 1945 - A preliminary note on the plankton of Bombay harbour, Current Science, 14, 8, 212-212.

18. Subramanyam T. V., Karindikar K. R. and Murthi N. N., 1952 - Marine gastropods of Bombay, Part I, Journal of University of Bombay, 21, 1, 21-34. 